\title{
Kristne barnehager
}

\section{Av Helje Kringlebotn Sødal og Olav Hovdelien}

Artikkelen gir ny kunnskap om kristne barnehager ${ }^{1}$ som utgjor omkring 4,5\% av norske barnehager. Vi redegjor for lovgrunnlaget og undersøker blant annet ulike livssynsvedtekter og hvordan et utvalg ansatte forstår mandatet sitt, og bidrar til å gjøre verdigrunnlaget og fagområdet etikk, religion og filosofi (ERF) synlig i hverdagen og ved hoytidene. En empirisk undersøkelse fra høsten 2019 og våren 2020 utgjør det viktigste empiriske materialet for artikkelen og omfattet 20 ansatte med pedagogisk ansvar $i 19$ barnehager $i$ Oslo og på Agder. Ti av barnehagene var kristne. I denne artikkelen presenteres resultater fra den delen av undersøkelsen som var rettet inn mot de kristne barnehagene. Vi tegner et komplekst bilde av tradisjons- og verdiformidlingen, samtidig som vi finner monstre. Formidlingen karakteriseres som plural. Den kristne formidlingen er metodisk sammensatt og utgjor en integrert del av barnehagehverdagen og den samlede virksomheten.

Nøkkelord: kristne barnehager, livssynsvedtekt, etikk, religion og filosofi (ERF), tradisjonsformidling, høytidsmarkering

\section{HelJe Kringlebotn SøDal, (f 1962), professor i kristendomshistorie ved Universitetet i Agder. Adresse: postboks 422, 4604 Kristiansand. E-post: helje.k.sodal@uia.no \\ Olav Hovdelien, (f 1968), professor i religion, livssyn og etikk ved OsloMet - storbyuniversitetet. Adresse: postboks 4, St. Olavs plass, 0130 Oslo.E-post: Olav.Hovdelien@oslomet.no}

Det er lang tradisjon for kristne barnehager i Norge. ${ }^{2}$ Likevel har knapt noen forsket på dem. Målet med denne artikkelen er derfor å gi ny kunnskap om barnehagetypen, dels nasjonalt og dels i to religiøst forskjellige fylker: Agder med sin høye kristne aktivitet, og Oslo med sitt store religionsmangfold og forholdsvis lave kristne aktivitet. Vi avgrenser oss til nåtiden og spør: Hvor mange kristne barnehager er det i Norge, og hvem eier dem? Hva er karakteristisk for kristne livssynsvedtekter, og hvordan oppfatter personalet dem? Hvem går i og er ansatt i kristne barnehager? Hvordan arbeider ansatte i et utvalg slike barnehager med verdigrunnlaget og fagområdet etikk, religion og filosofi (ERF)? Grunnen til at vi går bredt ut og har formulert flere forskningsspørsmål, er at vi ikke bare ønsker å gi ny kunnskap om kristne barnehager i to fylker, men også legge et mer generelt kunnskapsgrunnlag som kan utgjøre et startpunkt for senere forskning på denne delen av barnehagefeltet. Studier viser ellers at ERF gjennomgående er lavt

1 Med kristne barnehager forstås private barnehager som har vedtektsfestet et tillegg til barnehagelovens $₫ 1$ som knytter verdigrunnlaget til kristendommen.

2 Historisk går røttene tilbake til barnekrybbene som ble etablert i flere norske byer fra 1890-årene av med Frelsesarmeen, statskirkemenigheter og kristne organisasjoner som eiere, Wiesner 1924: 116-125.

Prismet - IKO-Forlaget 2020

Tilgjengelig på https://journals.uio.no/index.php/prismet. Publisert under CC BY-NC 4.0. Fagfellevurdert 
prioritert i barnehagen og klart minst vektet av de sju fagområdene (Østrem m.fl. 2009:25-28; Riksrevisjonen 2009:33-34; Winsvold og Guldbrandsen 2009:48). ${ }^{3}$ Vi forventet at det forholdt seg annerledes i de kristne barnehagene. Det er også påvist at private barnehager har arbeidet noe mer med dette fagområdet enn offentlige barnehager (Winsvold og Guldbrandsen 2009:50). I drøftingen av arbeidet med ERF i intervjubarnehagene utvides den svenske religionspedagogen Hjalmar Sundéns klassiske teori om verbal og total tradisjonsformidling (Sundén 1970). Vi innfører en tredje kategori, plural tradisjonsformidling, og argumenterer for at den ligger innenfor det kristne barnehager har rett til å gjøre ut fra lovverket.

\section{DET EMPIRISKE MATERIALET}

Store deler av denne artikkelen bygger på en kvalitativ undersøkelse vi utførte på Agder og i Oslo i perioden september 2019 til februar 2020. Dette hovedmaterialet består av semistrukturerte intervjuer med barnehageansatte med pedagogisk ansvar for innholdet og virksomheten i et utvalg barnehager, det vil si styrere og pedagogiske ledere. ${ }^{4}$ Spørsmålene handlet om informantens syn på og praktisering av barnehagenes formålsbestemmelse og fagområdet ERF, den livssynsmessige sammensetningen av ansatte og barn i barnehagen, foreldresamarbeid omkring tradisjons- og livssynsformidling og andre livssynsrelaterte tema. Intervjuene omfattet 20 ansatte i 19 barnehager. ${ }^{5} \mathrm{Ti}$ av barnehagene var kristne, én var jødisk, én var islamsk, mens de resterende ni var kommunale/offentlige barnehager (uten utvidet formål). I denne artikkelen bruker vi den delen av undersøkelsen som går på kristne barnehager, i alt ti institusjoner og ti informanter. Komparasjon mellom de kristne og de øvrige tros- og livssynsbarnehagene, eller mellom disse profilbarnehagene samlet sett og de kommunale/offentlige barnehagene, er ikke et hovedanliggende. Imidlertid bidrar enkelte likheter eller forskjeller i det samlede intervjumaterialet til å understreke sentrale poeng i drøftingen. I slike tilfeller viser vi kort til dem, men markerer da tydelig at vi trekker veksler på andre deler av materialet enn bare de kristne barnehagene.

Det empiriske materialet omfatter også vedtekter, årsplaner og andre dokumenter som vi fikk i forbindelse med intervjuene. I tillegg har vi hentet nettpubliserte vedtekter og årsplaner fra kristne barnehager i alle landsdeler, og med ulikt eierskap. Dessuten bruker vi barnehagens lov- og rammeverk, offentlig statistikk og annen forskning i den grad det finnes, i den hensikt å få et bredest

3 En nyere studie har avdekket at ingen av de åtte informantene viste interesse for ERF slik at de nevnte fagområdet blant dem de var opptatt av, Håberg 2019.

4 Utvalget av informanter begrunnes ut fra vår forforståelse av forskningsfeltet som er opparbeidet gjennom mer enn tyve års forskning. For diskusjoner av forutsetninger for bruken av denne formen for intervjuer, se Bryman 2004 eller Repstad 2007. Vår analyse av informantenes forståelse vil være dobbelthermeneutisk ved at vi forsøker å foreta en velbegrunnet forståelse av informantenes forståelse av feltet, med de begrensningene som ligger i en slik tilnærming (jf. Giddens 2003: 400-404).

5 I den ene (kommunale) barnehagen vi besøkte, stilte to ansatte til intervju. 
mulig grunnlag for vår forståelse av tematikken som undersøkes. ${ }^{6}$

Valget av informanter begrunnes $i$ at vi ønsket å snakke med dem som har ansvar for det pedagogiske innholdet og formidlingen i barnehagene. ${ }^{7}$ Informantene er anonymisert slik at vi ikke knytter sitater til bestemte barnehager, men til geografi og til eier der det fremstår som relevant. Utvalget av barnehager som danner grunnlaget for undersøkelsen, kan betegnes som strategisk da vi ønsket å ha alle de store eiergruppene i sektoren representert. Dessuten ønsket vi å ha en geografisk spredning som omfatter både bynære og mer landlige barnehager på Agder, og forskjellige bydeler i Oslo. Valget av Agder og Oslo skyldes at forskningsinstitusjonene vi er ansatt ved, ligger her. Samtidig anså vi det som en fordel at disse landsdelene er forskjellige religiøst sett, fordi det sannsynligvis ville gi større spennvidde i materialet enn om vi hadde konsentrert den empiriske undersøkelsen til ett fylke. I denne artikkelen har vi likevel ikke prioritert komparasjon basert på geografi, men heller lagt vekt på å få frem mangfold i sektoren. De delene av artikkelen som bygger på den kvalitative undersøkelsen, gir bare kunnskap om de ti kristne barnehagene som vi har besøkt. Det er ikke grunnlag for å generalisere funnene fra intervjuundersøkelsen.

\section{Private tros- og livssynsbarnehager - ANTALL OG EIERSKAP}

I 2018 var det $i$ alt registrert 263 private tros- og livssynsbarnehager i Norge, og ut fra barnehagelovens $§ 1 \mathrm{a}$ kan slike barnehager ikke være offentlig eid. ${ }^{8}$ I Oslo var det 18 tros- og livssynsbarnehager, og i de fem sørlandskommunene som undersøkelsen vår har omfattet, var 16 registrert som det. ${ }^{9}$ Av dette kan vi slutte at denne barnehagetypen står betydelig sterkere på Agder enn i Oslo, sett i forhold til folketallet. Statistikken for Agder omfatter bare kristne barnehager, mens tallene for Oslo også inkluderer et par muslimske barnehager, én jødisk barnehage, og minst én sekulær livssynsbarnehage. Nasjonalt er det flest kristne barnehager i Bergen kommune der 31 er registrert som dette. Eierskap og livssynsvedtekt fremgår ikke av den offentlige statistikken, men med noen få unntak som er nevnt ovenfor i Oslo, dreier det seg om kristne eiere og kristne tillegg til barnehagens ordinære formål.

Mange kristne barnehager eies av enkeltmenigheter og organisasjoner tilknyttet Den norske kirke, frikirker eller stiftelser. Menigheter og organisasjoner innen Den norske kirke utgjør den største gruppen barnehageeiere blant medlemmene

6 Det er generelt lite forskning på religion og livssyn i barnehagen, se Hovdelien 2018 for en forskningsoversikt. Jf. også Kunnskapsdepartementet 2018, som etterlyser mer forskning på feltet.

7 Undersøkelsen var økonomisk støttet av nettverk for profesjonsrettet forskning ved UiA, PRONETT.

8 Tall fra PBLs nettside barnehagemonitor, som henter tall fra Utdanningsdirektoratet/BASILs innrapportering https://www.barnehagemonitor.no/mangfold-og-eierskap/, lest 7.1.2020.

9 Fordelt slik: Lyngdal 3, Mandal 1, Kristiansand 7, Lillesand 1 og Grimstad 4. 
i IKO - Kirkelig pedagogisk senters barnehageregister, og er etter alt å dømme også størst totalt sett. ${ }^{10}$ Blant de kristne organisasjonene er Norsk Luthersk Misjonssamband (NLM) den største kristne eieren med 33 egne barnehager og syv som eies sammen med andre organisasjoner. ${ }^{11}$

Norges største private barnehagekjede, Læringsverkstedet, har totalt 235 barnehager hvorav 19 er kristne, Solkollen-barnehagene. De har felles pedagogisk opplegg for verdi- og kristendomsformidlingen, og mer enn 60 andre kristne barnehager har kjøpt tilgang til dette opplegget, inkludert flere i materialet vårt. ${ }^{12}$ Fra frikirkene er forholdsvis mange eid av pinsemenigheter, som ifølge IKOs medlemsregister har fem barnehager. Dette tallet har sunket de siste årene, blant annet på grunn av salg til Læringsverkstedet. Frelsesarmeen har fire barnehager. ${ }^{13}$ Intervjumaterialet vårt omfatter barnehager fra alle større eiergrupper med unntak for Bergens-konseptet Akasia, som nå har ni kristne barnehager.

\section{LOVGRUNNLAG OG VARIASJON I LIVSSYNSVEDTEKTER}

Etter siste lovendring (2008, gjeldende fra 2010), er alle norske barnehager forpliktet på det formålet som er formulert i lovens $\S 1$ og gjeldende rammeplan (2017). ${ }^{14}$ Privat- og offentlig eide barnehager har dermed en felles, verdimessig «kjerne». Samtidig har private barnehager rett til å formulere alternative formålsbestemmelser som et tillegg, vedtektsfeste «særlige bestemmelser om tros- eller livssynsformål», som det heter i §1a. Alternativt kan det vedtektsfestes at verdiene i lovens $\S 1$ ikke skal forankres i den kristne og humanistiske arv og tradisjon, men dette alternativet er ikke relevant for denne artikkelen. Formålet forplikter barnehagens eier og ansatte, og har en viktig funksjon for foresatte som søker og takker ja til barnehageplass.

Henvisninger til kristendommen er felles for livssynsvedtektene i kristne barnehager, men ellers er de forskjellige. Flere har brukt eller videreutviklet et av IKOs tre forslag til formuleringer som organisasjonens medlemsbarnehager har tilgang til, og som vi fikk tilgang til i forskningsøyemed. Følgende eksempler illustrerer variasjon og viser at eiere tolker rammeplanens bestemmelse om at det skal fremgå av vedtektene hva livssynsformålene innebærer (s. 12), noe ulikt. Livssynsvedtekten i Solkollen-barnehagene er kort og inneholder metodeinformasjon. Her står det følgende i Årsplan for 2019-20: «Læringsverkstedet Solkollen er

10 https://iko.no/barnehagekontorets-medlemmer, lest 7.1.2020. Omkring $25 \%$ av landets registrerte tros- og livssynsbarnehager er medlemmer i IKO.

11 http://nlm-barnehagene.barnehage.no/Innhold/Nyhet/80429, lest 7.1.20.

$12 \mathrm{https} / /$ laringsverkstedet.no/barnehage, lest 7.1.20. Antall brukere/kjøpere av opplegget er oppgitt av strategisk utvikler i Læringsverkstedet, Jarle Waldemar, 17.10 2019.

$13 \mathrm{http}: / /$ www.frelsesarmeen.no/no/vart_arbeid/barnehager/Velkommen+til+Frelsesarmeens++barnehager. b7C_wlrQ1m.ips, lest. 7.1.20.

14 For en diskusjon av ulike måter å forstå barnehagens formålsparagraf, se Hovdelien 2017:33-44 og Sødal 2018:20-34. 
verdimessig forankret i kristen tro og tradisjon. Dette verdigrunnlaget formidles blant annet gjennom sang og musikk, bibelfortellinger og kristen høytidmarkering». NLM-barnehagene fremhever foreldresamarbeid og hvilke verdier og holdninger oppdragelsen skal utvikle: «Barnehagen skal, i nær forståelse og samarbeid med hjemmet, hjelpe til med å gi barna kristen oppdragelse i et godt og trygt miljø. [...] og utvikle barnas evne og vilje til å samarbeide med andre, bære ansvar og ha omsorg for medmennesker, både i Norge og mellom folkeslag». ${ }^{15}$ Siste leddsetning er det eneste eksemplet på internasjonalt utblikk vi har funnet. Det reflekterer både rammeplanens formulering om å gi barn «internasjonale perspektiver» (s. 9), og at eier er en misjonsorganisasjon. Ellers virker noen av livssynsvedtektene IKO-inspirerte. Frelsesarmeens barnehager «bygger sin virksomhet på Frelsesarmeens kristne grunnsyn» og legger særskilt vekt på «å gi barna kunnskaper, erfaringer og opplevelser i kristen tro og tradisjon». ${ }^{16}$ I dette tilfellet er konfesjonstilknytningen poengtert, og ordlyden minner om formuleringer fra IKO. I undersøkelsen vår hadde også et par barnehager vedtekter som slår fast at barnehagen skal drives på evangelisk-luthersk grunn og etter Den norske kirkes bekjennelse.

Forholdet til eier og eiers konfesjon ble også tematisert i intervjuene. Da vi spurte om dette, var svarene nokså like. Barnehagene samarbeidet godt med eier og hadde av og til besøk fra eierrepresentant(er) og/eller deltok på enkelte arrangementer i eiers regi. En informant mente at de ansatte nok helte «mot det lutherske», men ellers er inntrykket vårt at den konfesjonstilknytningen vi fant $\mathrm{i}$ noen vedtekter, hadde begrenset betydning for barnehagehverdagen. Det felleskristne ligger i praksis til grunn for formidlingen i de barnehagene vi besøkte. Det felleskristne er også det vi kan lese ut av de årsplanene vi fant på nettet, uavhengig av eierskap og vedtektsformulering om konfesjon. Ett unntak vi fant gjennom nettsøk, er landets eneste katolske barnehage, St. Franciskus i Arendal, som har mye spesifikk katolsk formidling ifølge årsplanen for 2017-21. ${ }^{17}$

Enkelte barnehager uttrykker spissformulert det særskilte verdigrunnlaget i en visjon eller et motto: «At alle barna skal bli kjent med Jesus og kan bli venner med ham», lyder visjonen i en frikirkelig eid barnehage på Agder. «Såpe, suppe og frelse» er Frelsesarmeen-barnehagenes og Frelsesarmeens felles motto. Begge kortformuleringene formidler en forkynnelses- eller evangeliseringstanke som i mer modifisert variant finnes i alle livssynsvedtektene vi har sett: Barnehagenes eiere ønsker og er tydelige på at de vil gi barn kunnskap om kristendom, erfaringer med møter med kristne mennesker og opplæring i kristne holdninger og verdier. Verbet kan er imidlertid viktig i den førstnevnte visjonen og bør også tenkes inn i

15 http://nlm-barnehagene.barnehage.no/Innhold/Side/119, lest 23.4.2020.

16 Vedtekter, https://s3.eu-west-1.amazonaws.com/frelsesarmeen/Vedtekter-Regnbuen-pr-19-09-19-norsk-ogengelsk.pdf, lest 14.2.20.

17 http://www.barnehage.stfx.no/index.php?pageID=39, lest 14.2.20. Vi har ikke intervjuet i denne barnehagen. 
den siste. Det er en mulighet, ikke et krav å bli venn med Jesus, og omsorg for hele mennesket kan senere bli en innfallsport til å velge «frelse» $i$ kristen sammenheng.

\section{OPPFATNINGER OM EGENART}

På den ene siden understreker flere informanter at kristne barnehager har mye felles med barnehager som drives etter lovens ordinære formål. De legger først vekt på det allmennetiske i barnehagens verdigrunnlag. Dette synspunktet virker mer utbredt blant informantene i Oslo enn på Agder, men utrykkes i begge regioner. En styrer i Oslo omtaler barnehagen som en «vanlig nærmiljøbarnehage», og en informant på Agder understreker at de har «det samme verdigrunnlag som andre - og noe i tillegg. Vi har mer fokus på det kristne. Hvis ikke, ville jo foreldrene ikke fått det de søkte på.» En annen sørlending hevder at «veldig mye er likt, vi gjør det samme, men det kristne verdigrunnlaget ligger i bunnen», mens en i Oslo poengterer at «... vi er først og fremst en vanlig barnehage, med en ekstra dimensjon».

På den andre siden formidler samtlige informanter at det er forskjeller mellom egen barnehage og andre som har ordinært formål, og at det henger sammen med livssynsvedtekten. Dette handler ikke bare om mengde på verdi- og tradisjonsformidlingen, men også om holdninger i personalgruppen. En avdelingsleder på Agder forteller at hun opplevde det mer spenningsfullt å skulle realisere formålsparagrafens «kristne og humanistiske verdier» $i$ en offentlig barnehage enn $i$ en kristen: «Jeg følte det var vanskeligere å jobbe i en kommunal barnehage. [...] Personalet ble veldig usikre på ting [som] gikk på kristendom, og da er det lett å velge dette bort.» En Oslo-ansatt beskriver tidligere arbeid i det hun kaller en «livssynsnøytral» barnehage som «krevende». Flere som har erfaring fra offentlige barnehager, mener det er mer avklart hvordan de ansatte kan arbeide med verdigrunnlaget i barnehager med livssynsvedtekt enn i offentlige barnehager. "Alt skulle være så nøytralt, men jeg mener det ikke finnes noe som er nøytralt. Noe blir valgt bevisst bort», sier en sørlending om tidligere jobber i kommunale barnehager i Oslo og på Agder. Når vi sammenligner med informantutsagn fra de offentlige barnehagene i materialet vårt, er det en tendens til at ansatte i de kristne barnehagene uttrykker høyere bevissthet om praktiseringen av barnehagens verdigrunnlag i hverdagen enn det ansatte i barnehager med ordinært formål giør. Dette er ikke overraskende, da en må forvente at en livssynsvedtekt får betydning for både rekruttering av personale som er positive til verdigrunnlaget, tettere oppfølging på dette punktet fra eier, og at det arbeides med verdier på det jevne i personalgruppen. 


\section{BRUKERE OG ANSATTE}

Kristne barnehager er ikke eksklusivt for barn med aktiv kristen bakgrunn og ansatte som selv regner seg som kristne. Det finnes, naturlig nok, ikke offisielle tall for dette, og ingen av informantene definerer nærmere hva de legger i ordet «kristen». Uansett er det et visst livssynsmangfold blant brukere og ansatte i undersøkelsen vår. En avdelingsleder i en menighetsbarnehage i Oslo reflekterer: «20-30 $\%$ av familiene [...] er kristne, resten er ikke vant til å gå i kirken», sier hun og legger til at det er muslimske barn i gruppen. Fire av de kristne intervjubarnehagene har hatt eller har barn med annen religiøs bakgrunn enn tradisjonell kristendom flest muslimske, noen med bakgrunn fra Jesu Kristi Kirke av Siste Dagers Hellige og ett jødisk barn. Et par informanter tror de fleste barna har en eller annen form for kristen bakgrunn, «ellers ville de ikke søkt denne barnehagen», kommenterer en. I Oslo og på Agder anslår to informanter at omkring halvparten av barna kommer fra kristne hjem. Andre tallfester ikke og påpeker heller at barnegruppene er sammensatte. Flere mener at mange foreldre, også dem med minoritetsbakgrunn, bevisst søker plass i kristne barnehager: «Muslimske foreldre velger gjerne vår barnehage framfor de kommunale fordi de mener det er trygt og godt her. De har valgt oss, og vi tar hensyn til dem», sier en pedagogisk leder på Agder. Frelsesarmeen-barnehagen i Oslo har mange muslimske barn, og informanten hevder: «De aller fleste muslimene er glad for at vi er en kristen barnehage med tydelige verdier [...] heller kristendom enn ateisme og humanetikk [...] mener mange av de muslimske foreldrene [...] selv om noen er kritiske».

Alle vi har intervjuet, snakker om tilfredse foreldre og godt samarbeid som også kan gå på livssynsspørsmål. «Det har aldri vært noen foreldre som har sagt noe annet enn at de er glade for at barna får med seg de kristne verdiene og tradisjonene - selv om ikke alle er aktive kristne selv», sier en styrer på Agder. En annen sørlending forteller at de årlig evaluerer virksomheten sammen med foreldrene, og at de aldri har fått innspill om for mye kristendom. Tvert om har enkelte «ment vi hadde for lite tatt i betraktning at vi har et kristent formål». Dette utsagnet falt $i$ en av barnehagene med mye kristen formidling og nært samarbeid med eiermenigheten, så det forteller mer om at noen foreldre kan ha urealistiske forventninger til hva en kristen barnehage er, enn om at de ansatte har vært uprofesjonelle og neglisjert barnehagens vedtekter. Samtidig står foreldrekommentaren som et viktig apropos til forestillinger om at foreldre generelt frykter for mye kristen påvirkning. Noen ser ut til å ønske seg mer.

Ingen informanter forteller om fritaksønsker bortsett fra at enkelte muslimske barn ikke skal være med på kirkebesøk. Vi har ikke intervjuet foreldre og kan ikke uttale oss om deres syn på livssynsvedtekten, medvirkning og tilpasningsønsker ut fra egen tro. Generelt viser Utdanningsdirektoratets foreldreundersøkelse at foreldre i private barnehager er noe mer fornøyde enn foreldre i offentlige 
barnehager. ${ }^{18}$ Dette dreier seg imidlertid mest om tilfredshet over leker, utstyr og mattilbud som ikke står sentralt i vår undersøkelse.

Likestillings - og diskrimineringsloven tillater innhenting av opplysninger om søkers religion eller livssyn hvis opplysningene har avgjørende betydning for yrkesutøvelsen, og virksomheten har som formål å fremme bestemte livssyn eller religiøse syn (\$ 30). Likevel hevder ingen informanter at personlig, kristen tro er en ansettelsesforutsetning. En Oslo-barnehage har flere muslimske ansatte, og muslimer har hatt engasjementer ved en Agder-barnehage i materialet. En styrer understreker at de ikke spør om personlig tro på ansettelsesintervjuer, men er «tydelige på verdigrunnlaget vårt, og at de som skal jobbe hos oss, må være villige til å jobbe ut fra det. Ellers er det nok stort spenn i aktivitetsnivå blant både foreldre og ansatte». Spørsmål om konfesjonstilhørighet for ansatte virker lite aktuelt. For eksempel er styreren i en barnehage eid av en pinsemenighet ikke med i eiermenigheten, og frikirkelige og medlemmer i Den norske kirke jobber i samme kristne barnehager. Alle informanter snakker om at ansatte må være lojale mot livssynsvedtekten, og de fleste forutsetter villighet til å bidra aktivt i den kristne formidlingen. Informantene, som alle omtalte seg som aktive eller personlige kristne, forteller også om gode samarbeidsforhold blant de ansatte på tvers av livssyn.

\section{MetodemangFold og INTEGRASJON}

Intervjuene og årsplanene viser stort metodemangfold i den kristne formidlingen i de fleste barnehagene. De viser også likheter med tanke på hvor ofte det er planlagt, kristen formidling og i det at de samarbeider med eiermenighet eller -organisasjon. Stikkprøver fra årsplaner for andre kristne barnehager tyder på at funnene våre er i samsvar med et som er vanlig for denne barnehagetypen også ellers i landet. ${ }^{19}$ Hovedinntrykket vårt er at den kristne formidlingen er metodisk sammensatt og utgjør en integrert del av barnehagehverdagen og den samlede virksomhet. En styrer på Agder som fremhever fellestrekk mellom sin og andre barnehager, uttrykker samtidig integrasjonen poengtert: «... vi vever det kristne inn i det vi skal ha i barnehagen». For flere informanter handler dette også om en personlig, verdimessig integritet uttrykt i nestekjærlighet og omsorg: «Barna skal få møte det kristne her, møte et kristent sinnelag», sier en sørlending.

Materialet fra undersøkelsen gir grunnlag for å skille mellom det vi kan kalle høyprofilerte og lavprofilerte kristne barnehager, og årsplaner fra nettet underbygger dette skillet. Med høyprofilert sikter vi til barnehager som har mye kristen formidling, jevnlig kontakt med eiermenighet eller andre kristne institu-

18 https://www.udir.no/tall-og-forskning/finn-forskning/tema/foreldreundersokelsen/ (2018), lest 26.2.20. 19 Dette gjelder f.eks. Solborg barnehage (Normisjon) i Stavanger, Skauen kristelige barnehage (DELK) i Skien, Akasia i Bergen (20 barnehager hvorav 9 kristne), Trondhjems Asylselskaps barnehager i Trondheim ( 7 barnehager, stiftelse med nær tilknytning til Dnk), Domkirkens barnehage i Tromsø og Furuly kulturbarnehage (Betania) i Alta. 
sjoner i nærmiljøet, og som bruker de fleste eller alle metodene som beskrives nedenfor. Under intervjuet la informantene fra slike barnehager stor vekt på egen livssynsvedtekt og det spesifikt kristne. Med lavprofilert sikter vi til barnehager der den kristne formidlingen er mindre omfattende og metodebruken mer begrenset enn i de høyprofilerte. Det samme gjelder kontakten med eier eller andre kristne institusjoner. Informantene fra slike barnehager henviste omtrent like mye til verdiene i barnehagenes felles formål (§ 1) som til egen livssynsvedtekt. Det er særlig et par barnehager på Agder som utpeker seg som høyprofilerte og et par Oslo-barnehager som fremstår som lavprofilerte. De øvrige kan plasseres mellom disse ytterpunktene.

Her gir vi et kort utblikk til andre deler av det empiriske materialet vårt, og slår fast at metodemangfoldet i ERF og integrasjonsgraden av dette fagområdet $i$ hverdagen ifølge informanter og årsplaner er større i tros- og livssynsbarnehagene generelt enn i de kommunale/offentlige barnehagene. Den jødiske barnehagen i Oslo har ellers mye til felles med de høyprofilerte kristne barnehagene. Den islamske barnehagen vi besøkte, har kanskje mer til felles med de lavprofilerte. Her var den pedagogiske lederen vi intervjuet, opptatt av at dette var en helt vanlig barnehage i nærmiljøet.

Alle de ti kristne barnehagene i materialet hadde kristent bordvers og brukte kristne sanger og bibelfortellinger jevnlig. Faste barnebønner av typen «Kjære Gud ta hånden min» er også vanlig, og noen nevner «kristne rim og regler». Såkalt gjentagelsesbønn kan kanskje være en variant av sistnevnte og ble av og til praktisert i en barnehage eid av en pinsemenighet på Agder som var tydelig høyprofilert. Gjentagelsesbønn går ut på at den voksne sier en kort setning som barna repeterer, eksempelvis: «Kjære Gud» (rep.), «takk for barnehagen» (rep.), «vær med oss på tur i dag» (rep.). De fleste barnehagene har én fast kristen samling per uke, men enkelte har «intensivopplegg» med påfølgende perioder uten kristne samlinger. Alle informantene la stor vekt på de kristne høytidene, som vi kommer tilbake til.

I de kristne samlingene er det vanlig å bruke konkreter som lego, duplo og andre leker fra barnas hverdag fordi dette skaper nærhet og gjenkjennelse. Filmer, bøker, plansjer, tegning, flanellograf og dramatiseringer brukes også, og enkelte praktiserer filosofisk samtale. Flere forteller at kristne barnebøker alltid er tilgjengelig i lesekroken sammen med andre bøker. I det hele formidler mange informanter at de ønsker å legge til rette for å normalisere tro og trosuttrykk og la dette inngå naturlig i flere sammenhenger, også i spontane samtaler med barna når det er naturlig ut fra temaet. Det er også vanlig med regelmessig kontakt med eiermenigheten eller lokale kristne institusjoner. Denne kontakten kan bestå av at prest, pastor, kateket eller barne- og ungdomsarbeider besøker barnehagen og har en samling der, eller kan dreie seg om at barna og familiene deres inviteres 
til familiegudstjenester eller andre samlinger tilrettelagt for barn. Noen eiere har utviklet egne kristne opplegg og ressursbanker. Frelsesarmeen har ifølge en informant en egen «bibelformidlingspakke», og Solkollen-barnehagene bruker egenproduserte, pedagogiske idéhefter om høytider og bibelfortellinger. Heftene er knyttet opp mot rammeplanen, og mer enn 60 kristne barnehager over hele landet har kjøpt rettigheter til å bruke dem. ${ }^{20}$ Dermed ligger Solkollen-konseptet an til å bli en trendsetter i det kristne barnehagesegmentet på linje og delvis $\mathrm{i}$ konkurranse med IKO.

Bønn skiller seg ut som den mest kontroversielle metoden, men bordvers og faste barnebønner er gjennomgående brukt og kan i involveringsgrad sammenlignes med kristne barnesanger eller kristne kulturbærende sanger av typen julesanger. Flere informanter understreker likevel at barna ikke blir presset til å synge eller si dem frem. Fri bønn er ikke vanlig i barnehagene vi har besøkt, men forekommer av og til i de to høyprofilerte barnehagene på Agder. Det er en fra personalet, ikke et av barna, som da formulerer en enkel bønn med egne ord. De fleste informantene ser ut til å regne en slik bønneform som uttrykk for personlig trosutøvelse som primært hører hjemme andre steder enn i barnehagen, men en pedagogisk leder på Agder får en ny idé når vi spør om bønn: «... når vi snakker om det nå, får jeg veldig lyst til å ha fribønn med ungene», sier hun med et glimt i øyet. Hun presiserer at hun ikke tenker på vanlig, «voksen» fribønn, men på at barn som måtte ha lyst til det, kunne si noe til Gud hvis de selv ville. «Jeg ville aldri lagt barnebønn inn som fast 'post', men vi kunne ha gitt rom for at barn sa noe», legger hun til og understreket at det ville bli helt «feil» å skape forventninger om at barna måtte «be» på denne måten. Vi tolker refleksjonen til denne pedagogiske lederen som uttrykk for en åpenhet mot barnets verden også når den inneholder «en åndelig dimensjon» som det ifølge rammeplanen (s. 9) skal være rom for i barnehagen. Enkelte av metodene i den kristne formidlingen aktiviserer like fullt spørsmålet om forholdet mellom formidling, det å gi kjennskap til, som ifølge rammeverket er barnehagens mandat, og forkynnelse som ikke omtales direkte her.

\section{PEDAGOGISK VIRKSOMHET, FORKYNNELSE ELLER FORMIDLING?}

Barnehageloven slår fast at barnehagen skal være «en pedagogisk virksomhet» (§ 2) samtidig som rammeplanen presiserer om at «Den enkelte barnehage kan [...] ha en innfallsvinkel til formålsbestemmelsen som samsvarer med annen religiøs eller filosofisk overbevisning» (s. 12). På hvilke måter kan «religiøs overbevisning» uttrykt i livssynsvedtekten legitimt komme til uttrykk i kristne barnehager?

20 Samtale med produktutvikler i Solkollen, Jarle Waldemar 17.10.19. Vi har fått tilgang til seks slike ressurshefter. De er publisert uten utgivelsesår og forfatter, som muntlig oppgis å være produktutvikler. 
Rammeverket er ikke helt tydelig på det, og noen av informantene nøler når de blir spurt om forholdet mellom forkynnelse og formidling. Informantene understreker at barnehagen skal drive formidling i tråd med rammeplanen, og at de ikke stiller barn på trosvalg: «I barnehagen snakker vi om og forteller, men vi inviterer ikke til standpunkt», sier en, og flere påpeker at de ikke driver søndagsskole. Informanter som sa noe om forkynnelse, la vekt på at kristne barnehager ikke er steder anlagt for religiøs omvendelse, men steder der barn får kunnskap og erfaringer som de kan trekke veksler på senere, når de er modne nok til å ta selvstendige trosvalg. Flere distanserte seg tydelig fra forkynnelse. «Jeg legger bånd på meg selv når det gjelder forkynnelse», sier for eksempel en styrer i Oslo, men føyer til at en kollega med frikirkebakgrunn «kan være mer direkte i forkynnelsen». Dette virker informanten, en pedagogisk leder, noe betenkt over. En enhetsleder på Agder gir uttrykk for synspunkter som flere informanter deler, at trosvalg hører senere livsfaser til. Hun sier seg heldig som får formidle kristen kulturarv til barn og gi dem en ballast for livet, men «så må de ta selvstendige valg litt senere».

Et eksempel kan stille spørsmålet om forkynnelse og utfordring til trosvalg på spissen. Det dreier seg om ei jente på seks år i en menighetsbarnehage i Oslo, som uttrykte at hun hadde «møtt Jesus og nå ville hun døpe seg». Hun ba foreldrene om å få til dette. Styreren som fortalte om hendelsen, karakteriserte foreldrene som «ikke spesielt kristne», og de hadde åpenbart latt være å døpe jenta som spedbarn. Selv redegjorde styreren godt for skillet mellom formidling og forkynnelse i intervjuet, og vi har ikke grunnlag til å konkludere på om hendelsen indikerer at det har vært en form for livssynspåvirking $i$ denne barnehagen som går utover det lovverket regulerer. Alderen tatt i betraktning, vil vi heller ikke uten videre tolke jentas ønske som uttrykk for et selvstendig trosvalg. Kanskje det like gjerne kan tolkes som en form for medvirkning? Det er et åpent spørsmål om jenta hadde fått med seg hva kristen dåp handler om og valgte ut fra det. Men hendelsen viser i alle fall at jenta hadde fått lyst til å gjennomgå et kristent ritual på grunn av noe barnehagen hadde formidlet. Farens reaksjon på dåpsønsket understøtter tolkningen vår om medvirkning. Ifølge styreren takket han for at barnehagen hadde ivaretatt datterens «åndelige utvikling».

Noen informanter mener at barnehagen kanskje rekrutterer til eiers barnearbeid og uttrykker at vedtekten gir en viss rett til å forkynne. Noen synes også det er vanskelig å trekke skarpe skiller mellom kristent barnearbeid og barnehagens virksomhet. Én grunn er at deler av innholdet og flere metoder er felles og kan virke involverende. Drama og sang er for eksempel involverende, og en informant reflekterer rundt tradisjonsmaterialet som en form for indirekte forkynnelse: «... vi har jo fortellingene og forkynnelsen som ligger i disse». I samme retning trekker det at informantene svarer ut fra egen kristne tro hvis barna spør, men ingen sier at de forsøker å overbevise dem om at kristendommen eksklusivt er sann, rett 
og god. Inntrykket er at de mener dette er menighetenes oppgave. I barnehagen ønsker de både å formidle kristendom som kultur, tro og verdisystem, møte barna ut fra deres livssynsmessige forutsetninger og formidle respekt for ulike trosstandpunkt som barn og foreldre måtte ha. En informant poengterer at det er «greit» at barnehagens brukere gir uttrykk for andre livssyn enn kristendommen, og flere er åpne for å markere høytider fra andre religioner hvis de er representert i barnegruppen, noe en kan forvente ut fra rammeplanen (s. 55) som ikke har noe unntak for private barnehager med livssynsvedtekt.

Vi gir informantene rett $i$ at det er krevende å skille mellom forkynnelse, som verken barnehageloven eller rammeplanen omtaler direkte, og formidling som vanligvis forbindes med pedagogisk virksomhet. Rammeverket åpner generelt for at barnehagen bruker mer enn kognitive innfallsvinkler $i$ arbeidet med fagområdene. ERF er ikke unntatt, og særlig ikke arbeidet med dette fagområdet $\mathrm{i}$ tros- og livssynsbarnehager.

Den svenske religionspsykologen Hjalmar Sundén lanserte på 1970-tallet begrepsparet verbal og total tradisjonsformidling (Sundén 1970). De kan bidra til å forstå utviklingen i barns religiøsitet og premisser for religiøs tradisjonsformidling i norske barnehager (Sødal 1999: 57-59). Det er nærliggende å knytte verbal tradisjonsformidling til institusjonens mandat. Hos Sundén innebærer verbal tradisjonsformidling at formidlingen baseres på ord. I barnehagen kan det for eksempel dreie seg om bibelfortellinger og samtaler mellom barn og voksne. De voksne snakker eller forteller om Gud, kristen tro, etikk, tradisjoner og høytider til barn, eller barn spør og voksne svarer med saksopplysninger. Vanligvis er dette ansett som legitim formidling ut fra rammeplanen. Total tradisjonsformidling forutsetter derimot at voksne er religiøst aktive, og gudsforholdet blir viktig. Denne formidlingstypen kan assosieres med forkynnelse for å overbevise og skape tilslutning. Total tradisjonsformidling kan legitimt forgå i trossamfunn og hjem, men neppe i barnehager når det blant annet går ut på å innlemme barn i et religiøst fellesskap der de kan gjøre religiøse erfaringer sammen med andre. Voksne og barn snakker i denne formidlingsformen sammen til Gud, deltar i kristne ritualer $i$ et kristent fellesskap og så videre.

I møte med empirien vår blir Sundéns dikotomi for snever, og vi mener det finnes et mellomområde som det kan være vanskelig å definere skarpt, og som lovverket ikke gir entydige rammer for. I barnehagen dreier det seg ikke om enten formidling gjennom ord eller deltagelse i et kristent fellesskap, men om ord kombinert med andre formidlingsformer, og om fellesskap som ikke stiller barn overfor trosvalg, men gir variert kulturell, religiøs og verdimessig kunnskap og ulike impulser til å undre og interessere seg for trosspørsmål, som senere kan hjelpe barna til å velge eget livssyn. Det dreier seg heller ikke om avgrenset, planmessig tradisjonsformidling med f.eks. sporadisk arbeid med bibel- 
fortellinger, kristne, kulturbærende sanger eller kirkebesøk som i noen grad er involverende, men likevel gjennomførbart i barnehager med vanlig formålsparagraf. Mellomområdet vi sikter til, handler om å gi barna hyppige og varierte møter med kristen tro og tradisjon både gjennom spontane og planlagte aktiviteter. Den kristne formidlingen integreres i barnehagehverdagen og de øvrige pedagogiske aktivitetene uten at innhold, omfang, og metoder samlet sett gjør virksomheten om til et regulært kristent barnearbeid. På lignende vis er kristne, statsstøttede friskoler offentlig anerkjente pedagogiske virksomheter, ikke eiers trosopplæringstilbud.

Med en term som fremhever metode- og innholdsmangfoldet, kaller vi dette mellomområdet for plural formidling. Det kan gå ut på at voksne leser og forteller om kristendom og involverer barna i samtaler om dette, at det ofte synges kristne sanger, at barna stimuleres til å bearbeide formidlingen gjennom lek, drama, formingsaktiviteter og annen kreativitet, at (alle) de kristne høytidene markeres ved hjelp av varierte metoder, at kristne institusjoner i nærmiljøet besøkes, og at emner som handler om kristen tro og etikk, har plass i års- og ukeplaner, så vel som i spontane samtaler.

Det er plural tradisjonsformidling vi finner spor av og får fortellinger om gjennom planer og intervjuer i de kristne barnehagene, om enn i noe varierende grad i de høy- og lavprofilerte barnehagene. Her er det nærliggende å føye til at dette også gjelder for den jødiske og islamske barnehagen vi besøkte. Vi mener denne formidlingsformen prinsipielt er legitim ut fra barnehagens rammeverk og dessuten naturlig i private barnehager med livssynvedtekt. I praksis er det like fullt avgiørende viktig at pedagogisk ansvarlige og andre barnehageansatte bruker sitt profesjonelle skjønn til å vurdere om barnehagen er i ferd med å bevege seg over i total tradisjonsformidling og sette grenser for det. Informantene fortalte ikke om, og planer vi har tilgang til, viser ikke eksempler på praksis som vi mener strider mot rammeverket.

\section{Høytider}

Rammeplanen slår fast at personalet skal «gi barna kjennskap til og markere merkedager, høytider og tradisjoner i den kristne kulturarven og andre religioner og livssyn som er representert i barnehagen» (s. 55, vår utheving). Annen forskning viser at religion gjerne blir mest tematisert og synlig i barnehagen $i$ forbindelse med høytider, og primært før jul (Hovdelien 2018:289-292; Fauske 2012; Toft og Rosland 2014; Krogstad og Hidle 2015; Krogstad 2017). Kristne barnehager, både høy- og lavprofilerte, arbeider naturlig nok mye med dette. Gjennomgående legger de større vekt på den spesifikt kristne tradisjonsbakgrunnen for høytidene enn det de offentlige barnehagene i materialet vårt gjør. Dessuten tar de kristne barnehagene rammeplanens flertallssubstantiv på alvor. Her omfatter de 
pedagogiske oppleggene jul og påske, og vanligvis også pinse, Kristi himmelfartsdag og enkelte kristne merkedager. I så måte er det relevant med en kort sammenligning med de kommunale/offentlige barnehagene fra undersøkelsen vår. Selv om det var noe variasjon blant sistnevnte, virker de kristne barnehagene generelt mer lojale mot rammeplanen på dette punktet og formidler høytider i flertall. Dette funnet samsvarer med andre undersøkelser som viser at det primært er den kristne tradisjonsbakgrunnen som formidles (jf. Hovdelien 2018:289-292).

I religionsdidaktiske fremstillinger skilles det gjerne mellom markering og feiring av religiøse høytider (Winje 2010: 24-25; Sødal 2018: 107-109). Enkelt sagt handler markering om en pedagogisk, planlagt virksomhet som synliggjør høytidene og formidler kunnskap om dem. Feiring har sterkere preg av religiøs deltagelse og involvering, og regnes gjerne som en oppgave for menighet og hjem. Samtidig kan det være vanskelig å trekke en skarp grense mellom dem, og vi viser igjen til Sundéns sondring mellom verbal og total tradisjonsformidling som en mulig parallell til skillet mellom markering og feiring. I dette tilfellet blir også mellomkategorien vår, plural formidling, karakteristisk for høytidsoppleggene i de kristne barnehagene. Det er verken ren markering / verbal formidling eller feiring / total formidling her, men «litt begge deler», som en styrer i Oslo uttrykker det. Hun snakker både om «kulturformidling» og fester, og om et metodemangfold som minner om feiring: «Vi har påskefest og pinsefest på dagtid, der vi inviterer de som arbeider i staben [i lokalmenigheten] og foreldrene. [...] Juletrefest med julespill og foreldrebesøk, med gang rundt juletreet og det som hører med [...] vi forteller mye om advent, jul, påske osv.». Plural formidling er en dekkende betegnelse for slike sammensatte opplegg. Mens innslag som peker i retning av feiring / total tradisjonsformidling er lite aktuelle for barnehager uten livssynsvedtekt, er det vanskelig å avvise dette fullstendig i tros- og livssynsbarnehager. I det samlede materialet vårt, som altså også inkluderte kommunale/offentlige barnehager, samt en jødisk og en islamsk barnehage, er det den jødiske barnehagen som går lengst i retning av feiring / total tradisjonsformidling.

Mens mange informanter forteller om og er fornøyde med faste kirkevandringer til jul og påske, er det færre som deltar på barnehagegudstjenester. Slike gudstjenester ser langt på vei ut til å være erstattet med mer brukeraktive, men kanskje også mindre forkynnende/ «feirende» opplegg som høytidsvandringer og andre former for kirkebesøk. Gudstjenestedeltagelse kan i prinsippet karakteriseres som en form for feiring siden det følger kirkelige ritualer og gjerne legger opp til aktiv deltagelse fra barnas side. En jule- eller påskevandring kan derimot karakteriseres som enten feiring eller markering, alt etter hvordan de organiseres og formidlingen skjer. Det ser uansett ikke ut til å være noen stor fritaksproblematikk knyttet til «vandringer» eller gudstjenester. Foreldrene kjenner livssynsvedtekten og har ifølge informantene ikke innvendinger til høytidsmarkeringer og involve- 
ringsgrad. Unntaket er barn fra enkelte muslimske familier som ikke ønsker å være med på opplegg i kirken.

I flere av de kristne barnehagene vitner høytidsoppleggene om god sammenheng i tradisjonsformidlingen. Høytid og hverdag kontrasteres samtidig som de knyttes sammen gjennom fortellinger. «Vi bruker bibelfortellinger mye gjennom året, på mange måter [...] drama, tegning, kunst, leser og forteller», sier en styrer i Oslo. Fortellingsutvalget gir Jesus et liv mellom fødsel/jul og død/ påske, og den enkelte bibelfortelling settes inn i en større sammenheng. Som regel er dette annerledes i barnehager uten livssynsvedtekt, der det stort sett er fortellingen om Jesu fødsel som går igjen. En styrer på Agder forteller at de har et årshjul som viser hvilke bibelfortellinger som skal inn og når. Det er laget av en lokal arbeidsgruppe og starter med skapelsen om høsten. Så følger fortellinger om jul, deretter fortellinger om Jesu liv og hva han sa og gjorde. Så kommer påske, Kristi himmelfartsdag og pinse før året rundes av med fortellinger om himmelen. «På den måten har vi funnet en sammenheng i fortellingen om Jesus. Barna får med seg sammenhengen,» legger hun til. Solkollen-konseptet har høytidshefter med idébank, aktivitetsbank og forslag til utforming av «superfester». Disse barnehagene arbeider ut fra et treårig spiralprinsipp der de samme bibelfortellingene formidles flere ganger med nye innfallsvinkler, gradvis større fordypning, og ved hjelp av forskjellige metoder hvert år.

\section{Oppsummering: Profilerte og Pedagogiske}

Kristne barnehager har, som andre profilbarnehager, en distinkt profil - her i form av vedtekter som slår fast at virksomheten bygger på kristendom og kristne verdier. Dette gjelder omkring 4,5\% av landets barnehager, som eies av menigheter innen Den norske kirke, frikirkesamfunn, stiftelser og organisasjoner. Ut fra prosentandelen er profilen ikke spesielt fremtredende $i$ et samlet barnehagelandskap, men det er kristne barnehager i alle landsdeler. Sammenlignet med andre profilbarnehager utgjør de med sine 263 barnehager den nest største gruppen etter friluftsbarnehagene som teller 272 på landsbasis. Alle norske barnehager er underlagt barnehageloven og rammeplanen. Livssynsvedtekter er tillegg til dette, ikke erstatninger for det. En styrer på Agder formidler godt balansen mellom den kristne profilen og det at barnehagen er en pedagogisk institusjon: «Dette skal være en pedagogisk og faglig god barnehage som har Jesus i tillegg, ikke en barnehage som har Jesus og så litt faglig i tillegg», sier hun. Utsagnet kan være dekkende for det empiriske materialet vårt. Livssynsvedtektene er forskjellige, og enkelte har en skarpere kristen profil enn andre, samtidig som vi mener at ingen i materialet overskrider grensen for det pedagogisk forsvarlige. Informantene våre tolker egen livssynsvedtekt forskjellig og vektlegger ulike sider ved den, men alle uttrykker lojalitet til den. Barn som går i kristne barnehager, har forskjellig livssynsmessig 
bakgrunn. Sammenlignet med andelen aktive kristne i befolkningen er andelen barn som kommer fra aktive kristne familier, etter alt å dømme høyere i de kristne barnehagene enn ellers i befolkningen. Dette ligger i sakens natur, og det er kanskje mer overraskende at barn som kommer fra aktive kristne hjem, i flere tilfeller ser ut til å være i minoritet i materialet vårt. De ansatte har også forskjellig livssyn i de barnehagene vi besøkte, og ut fra informantenes opplysninger kunne mer enn halvparten karakteriseres som aktive kristne. Kristne barnehager på Agder og i Oslo preges av integrert og variert kristen formidling av en type vi kaller plural tradisjonsformidling. Det samme kan leses ut av årsplaner på nettet fra andre kristne barnehager.

\section{LitTERATUR}

Bryman, A. (2004) Social Research Methods. Second Edition. Oxford: Oxford University Press

Delanty, G. og Strydom, P. (red.) Philosophies of Social Science. The Classic and Contemporary Readings. Maidenhead: Open University Press

Fauske, R.H. (2012) «Bruken av religiøse forteljingar i barnehagen. Norsk tradisjon og manglande fleirreligiøsitet», Prismet 1:35-57

Giddens, A. (2003) «Social sience as a double hermeneutic». I Delanty, G. og Strydom, P. (red.) Philosophies of Social Science. The Classic and Contemporary Readings. Maidenhead: Open University Press, s. 400-404

Hovdelien, O. (2017) «Religion og sekularisme i barnehagens verdiforankring». I Hovdelien, O. (red.) Minoritetsreligioner i barnehagen. Bergen: Fagbokforlaget, s. $33-45$

Hovdelien, O. (2018) «Forskning på religion og livssyn i barnehagen. Oversikt og tendenser 1996-2018", Prismet 4:281-301

Hovdelien, O. (red.) (2017) Minoritetsreligioner i barnehagen. Bergen: Fagbokforlaget Håberg, I. L. (2019): «Verdiformidling til verdifulle barn i barnehagen». I Afset, A. og Redse, A. (2019) Religion og etikk i skole og barnehage. Oslo: Cappelen Damm Akademisk, s. 207-222

Krogstad, K. (2014) «Høytidsmarkering i barnehagen». Tidsskriftet FoU i praksis, 8(2), 51-69. Trondheim: Tapir Akademisk forlag

Krogstad, K. og Hidle, K.-M.W. (2015) «Høytidsmarkering i religiøst mangfoldige barnehager». Nordic Early Childhood Education Research, 9(6), 1-17.

Kunnskapsdepartementet (2018) Barnehagelarerrollen i et profesjonsperspektiv - et kunnskapsgrunnlag. Oslo: Departementenes servicesenter F-4450B

Lov om likestilling og diskriminering (likestillings- og diskrimineringsloven), https:// lovdata.no/dokument/NL/lov/2017-06-16-51 (hentet 26.2.20) 
Lov om barnehager (barnehageloven), https://lovdata.no/dokument/NL/lov/200506-17-64\#KAPITTEL_1 (hentet 30.1 2020)

Pareliussen, B.B. Moen, A. Reinertsen \& T. Solhaug (red.) (2013) FoU i praksis 2012 conference proceedings. Trondheim: Akademika forlag

Riksrevisjonens undersøkelse av styring og forvaltning av barnehagetjenesten. Dokument nr. 3:13 (2008-2009), Oslo: Departementenes servicesenter, http://evaluering. nb.no/eval-utlevering/innhold/URN:NBN:no-nb_overfortdokument_1605_ Eval_0/pdf (hentet 26.2.20).

Rammeplan for barnehagen. Innhald og oppgaver (2017), https://www.udir. no/globalassets/filer/barnehage/rammeplan/rammeplan-for-barnehagen-bokmal2017.pdf (hentet 26.2.20)

Repstad, P. (2007) Mellom narhet og distanse. Kvalitative metoder i samfunnsfag. Oslo: Universitetsforlaget

Rosland, K.T. \& Toft, A. (2013) «Markering av minoriteters høytider i barnehagen. En undersøkelse av forholdet mellom rammeplan og praksis». I I. Pareliussen, B.B. Moen, A. Reinertsen \& T. Solhaug (red.). FoU i praksis 2012 conference proceedings (s. 216-223). Trondheim: Akademika forlag

Sundén, H. (1970) Barn och religion. Verbum: Stockholm

Sødal, H.K. (1999) Kristen tro og tradisjon $i$ barnehagen. Kristiansand: Høyskoleforlaget

Sødal, H.K. (2018) Kristen arv og tradisjon i barnehagen. 6. utgave. Oslo: Cappelen Damm Akademisk

Wiesner, G. (1924) Norges Barneforsorg. Kristiania: Steenske Forlag

Winje, G. (2010) Høytidsmarkering i barnehagen. Kristiansand: Høyskoleforlaget

Winsvold, A. og Guldbrandsen, L. (2009): Kvalitet og kvantitet. Kvalitet i en barnehagesektor i sterk vekst. Oslo: NOVA Rapport 2/09

Østrem, S. (2009) Alle teller mer. En evaluering av hvordan Rammeplan for barnehagens innhold og oppgaver blir innfort, brukt og erfart. Rapport 1/2009. Tønsberg: Høgskolen i Vestfold

\section{NetTSider}

Utdanningsdirektoratet/BASILs innrapportering, https://www.barnehagemonitor.no/mangfold-og-eierskap/

https://iko.no/barnehagekontorets-medlemmer

http://nlm-barnehagene.barnehage.no

https://laringsverkstedet.no/barnehage

http://www.frelsesarmeen.no/no/vart_arbeid/barnehager/Velkommen+til+Fr elsesarmeens++barnehager.b7C_wlrQ1m.ips 
https://filadelfiabhg.no/uploads/1/2/0/1/120181823/vedtekter_ revidert_14.03.2019.pdf

http://tripptrapptresko.no/Innhold/Side/87029

http://www.frelsesarmeen.no/filestore/Bilder/Enhetene/Barnehager/

Regnbuen/PDF/VedtekterRegnbuenpr291110.pdf

http://www.barnehage.stfx.no/files/2018/01/vedtekter_2017.pdf 